

\title{
Modeling the creation of a Learning organization by using the Learning Organization Atlas Framework
}

\author{
Mijalce Santa, Selmin Nurcan
}

\section{To cite this version:}

Mijalce Santa, Selmin Nurcan. Modeling the creation of a Learning organization by using the Learning Organization Atlas Framework. 15th International Conference on Enterprise Information Systems (ICEIS'2013), Jul 2013, Angers, France. hal-01227451

\section{HAL Id: hal-01227451 \\ https://hal-paris1.archives-ouvertes.fr/hal-01227451}

Submitted on 11 Nov 2015

HAL is a multi-disciplinary open access archive for the deposit and dissemination of scientific research documents, whether they are published or not. The documents may come from teaching and research institutions in France or abroad, or from public or private research centers.
L'archive ouverte pluridisciplinaire HAL, est destinée au dépôt et à la diffusion de documents scientifiques de niveau recherche, publiés ou non, émanant des établissements d'enseignement et de recherche français ou étrangers, des laboratoires publics ou privés. 


\title{
Modeling the creation of a Learning organization by using the Learning Organization Atlas Framework
}

\author{
Mijalce Santa ${ }^{1,2}$ and Selmin Nurcan ${ }^{2}$ \\ ${ }^{1}$ Faculty of Economics - Skopje, Ss Cyril and Methodius University, blvd Goce Delcev 9V, Skopje, Macedonia \\ ${ }^{2}$ Centre de Recherche en Informatique, Université Paris I - Panthéon Sorbonne, 90 rue de Tolbiac, Paris, France \\ mijalce@eccf.ukim.edu.mk, selmin.nurcan@univ-parisl.fr
}

\begin{abstract}
Keywords: Learning Organization Atlas Framework, Learning Organization Grid, Learning Organization Road Map, Dynamic Model.

Abstract: In a continuously changing external environment, the learning organization can provide a competitive advantage. However, the concept has been largely criticized for the lack of guidelines and tools on how it could be developed. This undermines the opportunity for the development of the learning organization. This paper aims to contribute toward the debate on its creation by proposing a Learning Organization Atlas Framework approach. This framework comprises of the facets of the learning organization that characterize them, a Learning Organization Grid for the analysis and benchmarking of organizations, a Learning Organization Atlas that can be used for developing models of them, and a Learning Organization Road Map that includes the intentions of the organization and the strategies to achieve those intentions. With the framework and its four elements, we propose a method for modeling the learning organization and organizational change by providing embedded flexibility. The next level for research is in identifying the influence between different facets, strategy selection, and development of guidelines for models of learning organizations.
\end{abstract}

\section{INTRODUCTION}

A learning organization is an organization that facilitates the learning of all its members and consciously transforms itself and its context (Pedler et al., 1991). It is an organization skilled at creating, acquiring, interpreting, transferring, and retaining knowledge, and at purposefully modifying its behavior to reflect new knowledge and insights (Garvin, 2000). In today's complex external and internal environments, where vital planning assumptions continuously change, the learning organization is seen as a way in which the organizations sustain their competitiveness (Jashapara, 2004).

According to The Boston Consulting Group, in a world driven by innovation and rapid change, becoming a learning organization from top to bottom provides a clear competitive advantage and this will become more important in the future $(2008 ; 2010)$. A survey by the business magazine "Strategy+business" (Kleiner, 2005) ranked the idea of "the Learning Organization" as the second most enduring idea about strategy and business, among the 10 ideas that are most likely to last at least another 10 years.

Though the positive values of learning organizations, such as increased competitiveness have been widely discussed, critical aspects have also been raised, particularly the dilemmas related to its creation.

These criticisms are justified as until now only a limited understanding of how organizations can accomplish this exists and even less is available in terms of ideas supported by empirical research (Davis and Daley, 2008; Easterby-Smith et al., 1999; Tsang, 1997), and further, no practical operational advice (Garvin, 2000) or a template (Cavaleri, 2008) that managers can use is available.

Therefore, the mismatch between the strong expression of importance and need for learning organizations and the lack of capabilities, knowledge, and paths on how to create them strongly undermines the idea and its application. This paper aims to fill this gap. The purpose of the 
paper is to a) present a multilevel and multifaceted framework for the dynamic development of the learning organization and b) apply this framework on an example organization.

In the first part, the existing models on a learning organization are presented and discussed. Then, we present the Learning Organization Atlas Framework and show how the learning organization models can be developed and applied. We apply the framework and the modelling approach on an example organization. Finally, a conclusion and some perspectives on this work are presented.

\section{RELATED WORK}

The most known models in the learning organization literature are the energy flow model (Pedler et al., 1991), Senge's model (Senge, 1990), seven dimensions of the learning organization (Watkins and Marsick, 1993), and learning organization building blocks (Garvin et al., 2008). All these models are normative and suggest that learning can occur only under certain conditions. The leaders and the organization need to create those conditions through disciplined action or intervention. If the organization does not meet these conditions, it cannot learn.

Pedler et al. (1991) focus their model on movement and identify flows that can move: a) vertically from an individual to the collective and vice versa linking ideas and policy and $b$ ) horizontally from vision to action and vice versa linking actions and operations. These flows are supported by eleven characteristics that create the learning organization:

- The learning approach to strategy

- Participative policy making

- Informating

- Formative accounting and control

- Internal exchange

- Reward flexibility

- Enabling structures

- Boundary workers as environment scanners

- Inter-company learning

- Learning climate

- Self-development opportunities for all

Although this model tries to have an integrated approach toward the learning organization, it cannot be used for its development. The main shortcoming of this model is that it neither defines the relations between the elements nor on how the interactions between the flows should be done.
Senge (1990) identified five elements that are important for the learning organization: building a shared vision, personal mastery, working with mental models, team learning, and systems thinking. He does not structure the elements in a model and does not provide a clear picture on the relations between these elements. A characteristic of this model is that it introduces systemic thinking to the learning organization and identifies it as an element that underlies all the other elements.

Through the seven dimensions of the learning organization model, Watkins and Marsick (1993) view it as one that has the capacity to integrate people and structures in order to move toward continuous learning and change (Yang et al., 2004). The model is structured around four levels: individual, teams, organization, and society. For each level, they identified seven distinct but interrelated dimensions of a learning organization:

- Continuous learning

- Inquiry and dialogue

- Team learning

- Empowerment

- Embedded systems

- Systems connection and

- Strategic leadership

This model is clearly organized and structured. However, two shortcomings are identified. First, a lack of the developmental aspect that presents the levels that these dimensions can have, and second, a lack of clear identification of the organizational and team dimensions on the individual dimensions.

The learning organization building blocks model has identified three blocks that support the development of the learning organization:

- a supportive learning environment that consists of psychological safety, appreciation of differences and openness to new ideas, and time for reflection,

- concrete learning processes and practices consisting of experimentation, information collection, analysis, education and training, and information transfer, and

- leadership that reinforces learning.

This model does not identify the levels in the learning organization and lacks identification of the influence of all the blocks on the individual who is learning in the organization.

In Table 1, a comparative overview of the models is presented ( 1 is low, 5 is high). The comparison is based on the number of facets that are included in the models, levels of development of the 
facets, identification of the relations between the facets and the possibility to use the model for LO development. Overall the table presents that the existing models provide rather poor base for mapping and developing the learning organization.

Table 1: Evaluation of the models.

\begin{tabular}{|l|c|c|c|c|}
\hline Authors & Domains & Levels & Relations & Develop \\
\hline Pedler et al., (1991) & 4 & 1 & 1 & 1 \\
\hline Senge, (1990) & 3 & 2 & 3 & 2 \\
\hline $\begin{array}{l}\text { Watkins and } \\
\text { Marsick, (1993) }\end{array}$ & 3 & 4 & 3 & 2 \\
\hline Garvin et al., (2008) & 3 & 2 & 3 & 2 \\
\hline
\end{tabular}

According to (DiBella, 1995), there are two other perspectives to the learning organization: developmental and capability. The developmental perspective sees a learning organization as a stage in the organization's development. There are different styles and processes for different stage. Although this perspective provides more flexibility in becoming a learning organization, it does not identify that the learning is indigenous to organizational life. The capability perspective proposes that each organization learns through its own learning processes embedded in the organization's culture and structure.

The capabilities perspective legitimates a pluralistic view toward learning and learning style (DiBella, 1995) and provides the flexibility in the organization to create its own path toward becoming a learning organization.

The three perspectives, although conflicting in some aspects, when combined with each contribute to the understanding of the learning organization (DiBella, 1995). The normative perspective provides the vision that serves as focal point or target for change. The developmental perspective considers the history and shows how learning is contingent on the organization's stage of development. The capability perspective uncovers the transparency of the present.

Although it can be expected that there are clear guidelines on how to organize the process of creating the learning organization, it is not the case. Only some books provide a step-by-step guideline (Kline and Saunders, 2010; Marquardt, 1996; Pearn et al., 1994) but that is more related to change management than to a learning organization. A different approach is used by King (2001) who proposes six distinctly different strategies through which the learning organization can be achieved:

- Information systems infrastructure

- Intellectual property
- Individual learning

- Organizational learning

- Knowledge management

- Innovation

As King notes none of these strategies, if applied alone, is sufficient. There is a need for their combination.

\section{LEARNING ORGANIZATION ATLAS FRAMEWORK}

In order to develop a dynamic model that will enable the creation of the learning organization the following aspects should be taken into account. First, the learning organization is a multi-faceted construct (Yang et al., 2004). It has too many facets, attributes, and variables that need to be taken into account. Second, the relationships within the facet and between the facets are complex and determine how the learning organization will be developed (Grieves, 2008). Third, the learning organization is a chameleon-like target (DiBella, 1995), it is not a state that can be achieved, but a continuous journey, a journey on which the organization will continuously learn and change to stay on the edge of chaos (Waldrop, 1992). Fourth, there is no single approach to build a learning organization because each approach should be customized by taking into account the characteristics of the individual organization (Redding, 1997). Taking in account these aspects, we propose the Learning Organization Atlas Framework that consists of four elements: Learning Organization Facets, Learning Organization Grid, Learning Organization Atlas, and Learning Organization Road Map. This framework with its elements provides a systematic way of dealing with learning organization modeling and organizational change by providing embedded flexibility.

\subsection{Learning organization facets}

Through an extensive literature review, eleven facets of the learning organization were identified. The learning facet is identified as a core facet, while the others are distributed to four pillars that support the learning in the organizations.

- Direction pillar - vision and strategy

- Infrastructure pillar - structure, technology, and processes

- Informal pillar - culture, power, and politics 
- Change pillar - change and leadership

\subsection{Learning organization grid}

Each facet is looked through a Learning Organization Grid (LOG) that is a result of the combination of the learning entities in the organization and the levels of learning. We have identified three entities (individual, team, and organization) and four levels of learning (zero, one, two, and three). The entities and the levels of learning are identified through an extensive literature review and are a summary of the work of different authors (Senge, 1990; Marsick and Watkins, 1993, Pedler et al., 1991; Argyris, 1999).

On an individual level

- Zero learning - receipt of information which may lead to learning, but are not learning events

- Learning level 1 - skill learning, that is, making choices within a simple set of alternatives. Also known as single-loop learning (Argyris, 1999), or adaptive learning (Senge, 1990).

- Learning level 2 - choosing between sets within which level 1 learning takes place. Also known as double-loop learning (Argyris, 1999), or generative learning (Senge, 1990).

- Learning level 3 - learning to learn, also known as deutero-learning (Argyris, 1999).

For each individual level of learning, an appropriate team and organization level should be identified. On a team level the following type of teams are identified:

- Meet - the teams only meet and exchange information for mere reporting purpose with no goal to support learning

- Discuss - the team members try to tell and sell their opinion and to gain opinion on one meaning.

- Dialogue - to inquire, learn, unfold shared meaning, and uncover and examine assumptions.

- Integrate - to integrate multiple perspectives and to jointly create new perspectives.

On an organizational level, we have the following levels:

- Waste - the organization is not recognizing the knowledge it has or the need to manage that knowledge.

- Store - the organization is collecting the information and knowledge that is circulating

\begin{tabular}{|c|c|c|c|}
\hline Level 3 & $\begin{array}{l}\text { Meta learning } \\
\text { (I3) }\end{array}$ & $\begin{array}{l}\text { Integrate } \\
\text { (T3) }\end{array}$ & $\begin{array}{c}\text { Create } \\
\text { (O3) }\end{array}$ \\
\hline Level 2 & $\begin{array}{l}\text { Transformative } \\
\text { (I2) }\end{array}$ & $\begin{array}{l}\text { Dialogue } \\
\text { (T2) }\end{array}$ & $\begin{array}{l}\text { Disseminate } \\
\quad(\mathrm{O} 2)\end{array}$ \\
\hline Level 1 & $\begin{array}{l}\text { Adaptive } \\
\text { (I1) }\end{array}$ & $\begin{array}{c}\text { Discuss } \\
\text { (T1) }\end{array}$ & $\begin{array}{l}\text { Store } \\
\text { (01) }\end{array}$ \\
\hline \multirow[t]{2}{*}{ Level 0} & $\begin{array}{c}\text { Transactional } \\
\text { (I0) }\end{array}$ & $\begin{array}{l}\text { Meet } \\
\text { (T0) }\end{array}$ & $\begin{array}{l}\text { Waste } \\
(\mathrm{O} 0)\end{array}$ \\
\hline & Individual (I) & Team $(\mathrm{T})$ & Organization $(\mathrm{O})$ \\
\hline
\end{tabular}

Figure 1: Learning organization grid applied on the learning facet.

in the organization and stores it in various ways. Limited distribution of this knowledge is available to the teams and individuals.

- Disseminate - the collected knowledge is made available to teams and individuals in various ways and it can be easily used in their learning.

- Create - the organization is creating new knowledge that it provides to the individuals and teams in the organization.

Figure 1 presents the result we get when we look on the learning facet through the LOG and Figure 2 for the technology facet.

Each grid results in nine cells per facet. We have identified four types of relations between the cells (Figure 3):

- intra-cell (A) that could initiate translational change,

- intra-level (B1 and B2) where B1 initiates translational, while B2 transformational change,

- inter-level (C) initiates transformational change, and

- inter-grid are the relations between the cells of different facets. All the previous relations are a part of this type of relation and can result in

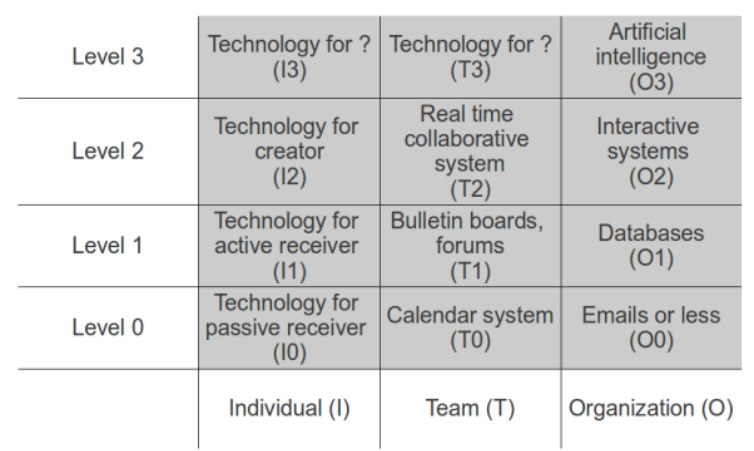

Figure 2: Learning organization grid applied on the technology facet. 


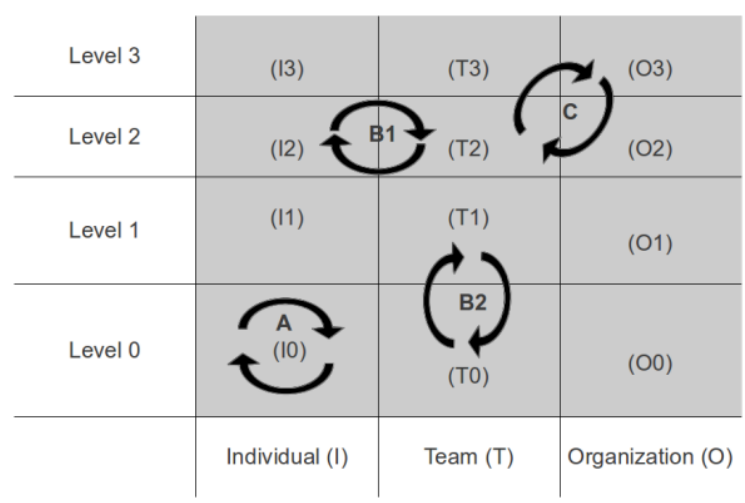

Figure 3: Relations within the Learning Grid.

translational and transformational changes.

\subsection{Learning organization atlas}

The LOG enables us to create a map of each Learning Organization Facet that it is identified. However, the facets are interrelated and influence each other so that the real value is achieved when the maps are layered on each other and the relations are identified. Depending on the purpose of the research, all or some of the maps can be layered. To achieve this, we will use the Learning Organization Atlas (LOA) (Figure 4).

By layering facet maps created with the same grid through the LOA, the following can be achieved:

- identify how the cells within an individual facet are aligned and what needs to be changed,

- identify how different facets are aligned and based on that, make decisions on what needs to be changed in order to become a learning

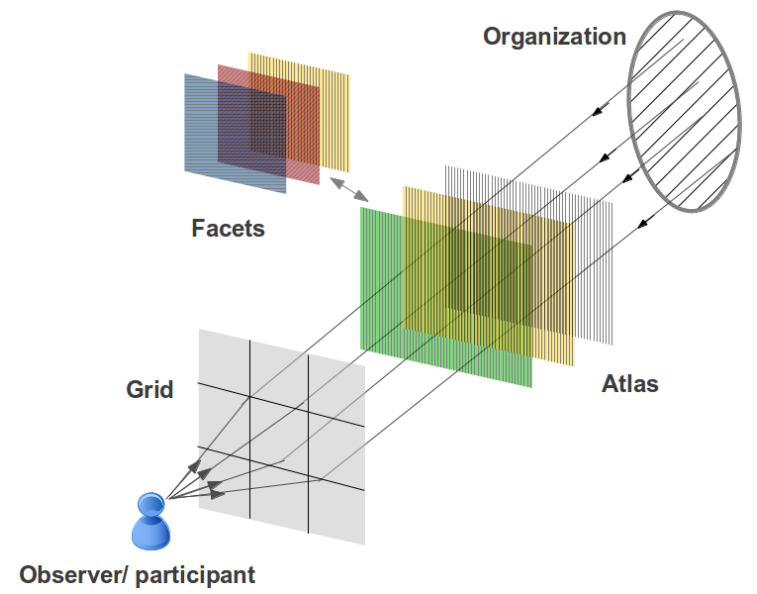

Figure 4: The Learning Organization Atlas. organization, and

- the organizations can create a customized learning-organization atlas model that will fit their characteristics and needs.

To facilitate the process of making decisions and taking steps for changing the organization and making a customized learning organization model the organization can use the Learning Organization Road Map.

\subsection{Learning Organization Road Map}

In reality, an organization is a dynamic entity that is changing continuously. Organizations need to have tools that will help them to change and sustain this competitiveness. The Learning Organization Road Map (LORM) based on results of the LOA provides guidelines to the organizations, their learning needs, and the required changes to be made. LORM is built on the propositions made by the map model of Rolland et al. (1999). According to them, a map is a process model in which a non-deterministic ordering of intentions and strategies has been included. The map is composed of one or more sections (Rolland and Prakash, 2001). A section is an aggregation of two kinds of intentions, the source and target intentions together with a strategy represented as < source intention $\mathrm{Ii}$, target intention $\mathrm{Ij}$, strategy $\mathrm{Sij}>$. An intention is a goal that can be achieved by the performance of a process. There are two special intentions, Start and Stop, to begin and end the map respectively. A strategy is an approach, a manner to achieve an intention. It characterizes the flow from Ii to $\mathrm{Ij}$ and the way $\mathrm{Ij}$ can be achieved. Because the next intention and strategy to achieve it are selected dynamically, guidelines that make available all choices open to handle a given situation are of great importance. The map has three guidelines,

- 'Intention Selection Guideline' per node Ii, except for Stop. Given an intention Ii, an Intention Selection Guideline (ISG), identifies the set of intentions $\{\mathrm{Ij}\}$ that can be achieved in the next step

- 'Strategy Selection Guideline' per node pair $\langle\mathrm{Ii}, \mathrm{Ij}\rangle$. Given two Intentions $\mathrm{Ii}, \mathrm{Ij}$, and a set of possible strategies Sij1, Sij2, ..Sijn applicable to $\mathrm{Ij}$, the role of the Strategy Selection Guideline (SSG) is to guide the selection of a Sijk.

- 'Intention Achievement Guideline' per section $<\mathrm{Ii}, \mathrm{Ij}, \mathrm{Sij}>$. Intention Achievement Guideline (IAG) that provides an operational or an 
intentional means to fulfill a business intention.

Each map is represented as a directed graph from Start to Stop. In the graph, the intentions are represented as nodes and strategies as edges between these. The graph is directed because the strategy shows the flow from the source to the target intention.

\section{APPLICATION}

In this section, we illustrate the process of development of a dynamic model of the learning organization. Organization $\mathrm{X}$ pressed by competition and a changing environment decides to fulfill the learning organization requirements and to be on level 3 cells for each entity on each facet. To achieve this it first needs to analyze the existing situation in the organization, benchmark the results to the learning organization characteristics, and then to align the cells in the facets and between the facets to fulfill the learning organization (LO) requirements. Based on the above, the intentions are:

- Intention 1 - analyze the facets

- Intention 2 - align the facets

- Intention 3 - fulfill LO requirements

To achieve intention 1 the organization can use formal (S1) or informal strategy (S2). By formally applying the LOG and defining the processes through which the information will be collected, it can be expected that Intention 2 will be achieved. However, a strategy that is more informal can be used to get an introductory view of the position of the organization $\mathrm{X}$.

- To move from intention 1 to intention 2, the organization can apply two strategies: align cells within a facet (S3) or/and align cells between the different facets (S4). These strategies are based on the identified relationships within the LOG and LOGs of different facets.

- To move from intention 2 to intention 3, the organization can apply four strategies: transformational (S5), incremental (S6), supported from outside (S7), and internally managed (S8). Strategies S5 and S6 are based on the type of changes that are required to move the organization from one cell to the next level of cell. Strategy S8 is based on literature review, where it is suggested that in the process of becoming a learning organization an external expert with knowledge and practical experience of a learning organization should be involved. S8 is proposed in order to give flexibility to the organization to develop into a learning organization with its own resources.

- After the realization of intention 3, the company can apply a strategy of keeping the new status (S9) or keeping the company open for change (S10). The learning organization is a continuous journey, so S10 should provide a way for this to be achieved. On the other hand, S9 can be used when there are no new internal or external pressures to make new changes in order to stay as a learning organization.

All these relations are presented in the global map (Figure 5).

To achieve intention 1, we opt for strategy 2 and use the LOG on the learning and technology facet presented in Figures 1 and 2. The following have been identified for the learning facet: The individuals are practicing adaptive learning and as a result, they make choices within a simple set of alternatives (cell I1). The teams exist but they only meet and exchange information for a mere reporting purpose with no goal to support learning (cell T0). The organization is collecting the information and knowledge that is circulating in the organization and stores it in various ways. However, limited distribution of this knowledge is available to the teams and individuals (O1).

Regarding the technology facet, the analysis reveals that the majority of the individuals in the organization have computers on which they mainly use the internet browser, email application, and office package (I0). The teams have bulletin boards, forums, and some team tools (T1); however, the majority of team members only read the information, while only a small number of persons publish on it. On the organizational level, the

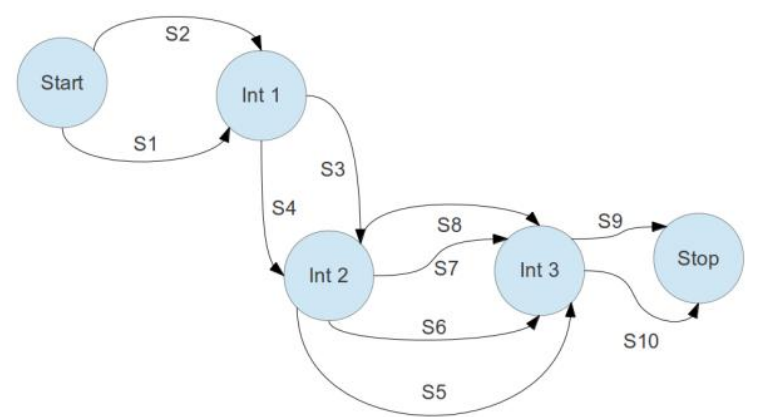

Figure 5: Learning organization <source intention Ii, target intention $\mathrm{Ij}$, strategy $\mathrm{Sij}>$. 
organization uses the email system for communication within the company $(\mathrm{O} 0)$.

By using the LOA, we can identify that Organization $\mathrm{X}$ is not fulfilling the principles of the LO (at level 3). Furthermore, there is misalignment between the cells within both facets.

One important aspect of using the LORM is that the global map can be decomposed in refined maps that will show the intentions and strategies at a more detailed level, for example, for the section <Analyze the facets, Align Facets, Align cells within a facet strategy>. The refined map for the learning facet is presented in Figure 6.

The following intentions were identified:

- Intention 1 - vertical alignment of each entity to be on level 3; and

- Intention 2 - horizontal alignment of each entity to be on the same level.

Strategies for vertical alignment are divided as per the entity:

Strategies for individuals:

- Informal learning (S1.1) that includes learning at work and action learning; and

- Formal learning (S1.2) that is based on trainings and formal courses.

Strategies for teams:

- Formal training for work in teams (S1.3); and

- Team competition (S1.4) that is based on same teams working on same issues and creating redundancy (Nonaka, 1994).

Strategies for the organization:

- Developing formal systems (S1.5) for collecting, storing, and distributing information and knowledge; and

- Developing informal systems (S1.6)for collecting, storing, and distributing information and knowledge (Pedler et al., 1991; Watkins and Marsick, 1993).



Figure 6: Refined map.
The strategies for horizontal alignment are:

- Anticipation strategy (S1.7) based on the perception of the organization that a certain entity is underperforming in certain facets and self-initiating the changes in that facet; and

- Push strategy (S1.8) were the organization has not self-initiated the changes, but now, owing to incompatibility with other facets the organization cannot function properly and it is pushed to change.

Based on the selection of the strategies the process will be ended with:

- Formal proposal for action (S1.9).

By developing a refined map for each section, we create a detailed road map that the organization can use to develop a customized and own approach in becoming a learning organization. The map can be refined up to a level of business processes, wherein a business process chunk is developed. The business process chunk will specify the roles, actors, and their activities through which the strategies can be realized and intentions achieved.

By using an intention-driven model, it is easier to highlight the business intentions and strategies. Furthermore, the road map model provides a priori flexibility since the navigation will be dynamically performed during the execution.

\section{CONCLUSIONS}

In this paper, we have proposed the Learning Organization Atlas Framework as a modelling approach for the LO. We have proposed a Learning Organization Grid that can be used for analyzing and benchmarking organizations toward the Learning Organization Facets. Then, we presented the Learning Organization Atlas, which can be used to develop learning organization models. In the next section, we introduced the Learning Organization Road Map as an intentional model of the learning organization. Through it, we demonstrated the flexibility with which the learning organization can be developed based on the business intentions and the strategies that the organizations can use. At the end, we presented an example of how all the three elements can be used to develop a LO.

A major advantage of our proposed approach is the systematic way of dealing with learning organization modelling and organizational change. Furthermore, it has an embedded flexibility that 
enables it to be used for development of tools and information systems for different organizations by type and size. When compared with the other models (Table 1) LOAF provides better ground for developing the Learning organization because it:

- Enables the organizations to include more facets in their analysis (11 in total) or add other facets not identified here.

- Clearly identify the levels that are important for analysis of the facets.

- Creates a structure through which in a more clear way the facets relations and development paths can be identified and justified.

For the future, we have identified three avenues for research. First, the identification of the influence between cells in the same facet and the influence of one facet on the other facets. Second, adding identification of which strategies can be best utilized to achieve the goal of becoming a LO. Third, the development of clear guidelines, that support the selection of intentions and strategies, and the achievement of those strategies. By researching in these three areas, our proposed approach can be strengthened and applied to more organizations

\section{REFERENCES}

Argyris, C., 1999. On Organizational Learning, WileyBlackwell., 2nd ed.

Cavaleri, S.A., 2008. Are learning organizations pragmatic? The Learning Organization 15, 474-485.

Davis, D., Daley, B.J., 2008. The learning organization and its dimensions as key factors in firms' performance. Human Resource Development International 11, 51-66.

DiBella, A.J., 1995. Developing learning organizations: A matter of perspective. Academy of Management Journal 38, 287-290.

Easterby-Smith, M., Araujo, L., Burgoyne, J., 1999. Organizational Learning and the Learning Organization: Developments in Theory and Practice, Sage Publications Ltd., 1st ed.

Garvin, D.A., 2000. Learning in Action: A Guide to Putting the Learning Organization to Work. Harvard Business Press.

Garvin, D.A., Edmondson, A.C., Gino, F., 2008. Is yours a learning organization? Harvard Business Review 86, 109.

Grieves, J., 2008. Why we should abandon the idea of the learning organization. The Learning Organization 15, $463-473$.

Jashapara, A., 1993. The competitive learning organization: A quest for the Holy. Management Decision 31, 52.
Jashapara, A., 2004. Knowledge Management: An Integrated Approach. Pearson Education Limited, Essex.

King, W.R., 2001. Strategies for creating a learning organization. Information Systems Management 18, 12.

Kleiner, A., 2005. Our 10 Most Enduring Ideas. strategy+business Winter 2005.

Kline, P., Saunders, B., 2010. Ten Steps to a Learning Organization, Great River Books., 2nd ed.

Marquardt, M.J., 1996. Building the Learning Organization: A Systems Approach to Quantum Improvement and Global Success. Mcgraw-Hill.

Marsick, V.J., Watkins, K.E., 2003. Demonstrating the Value of an Organization's Learning Culture: The Dimensions of the Learning Organization Questionnaire. Advances in Developing Human Resources 5, 132-151.

Nonaka, I., 1994. A Dynamic Theory of Organizational Knowledge Creation. Organization Science, 5(1), pp.14-37.

Örtenblad, A., 2007. Senge's many faces: problem or opportunity? Learning Organization, The 14, 108-122.

Pearn, M., Wood, R., Fullerton, J., Roderick, C., 1994. Becoming a learning organization: how to as well as why, in: Towards the Learning Company: Concepts and Practices. McGraw-Hill, pp. 186-199.

Pedler, M., Burgoyne, J., Boydell, T., 1991. The Learning Company: A Strategy for Sustainable Development, McGraw-Hill Publishing Co., 1st ed.

Redding, J.C., 1997. Hardwiring the Learning Organization. Training and Development 51, 61-67.

Rolland, C., Prakash, N., 2001. Matching ERP system functionality to customer requirements, in: Fifth IEEE International Symposium on Requirements Engineering, 2001. Proceedings. pp. 66-75.

Rolland, C., Prakash, N., Benjamen, A., 1999. A MultiModel View of Process Modelling. Requirements Eng 4, 169-187.

Senge, P.M., 1990. The Fifth Discipline: The Art and Practice of the Learning Organization, Doubleday Business., 1st ed.

Tosey, P., 2005. The hunting of the learning organization A paradoxical journey. Management learning 36, 335.

Tsang, E.W.K., 1997. Organizational learning and the learning organization: a dichotomy between descriptive and prescriptive research. Human relations 50, 73-89.

Waldrop, M.M., 1992. Complexity: The Emerging Science at the Edge of Order and Chaos, Simon \& Schuster. 1 st ed.

Watkins, K.E., Marsick, V.J., 1993. Sculpting the Learning Organization: Lessons in the Art and Science of Systemic Change, Jossey-Bass., 1st ed.

Yang, B., Watkins, K.E., Marsick, V.J., 2004. The construct of the learning organization: Dimensions, measurement, and validation. Human Resource Development Quarterly 15, 31-55. 